\title{
ゲノム医療に求められるシステム構築と人材について
}

\author{
四十物絵理子, 西 原 広 史*
}

\section{Required Human and System Resources for Genomic Medicine}

\author{
Eriko Aimono and Hiroshi Nishihara* \\ Division of Clinical Cancer Genomics, Keio University School of Medicine; \\ 35 Shinanomachi, Shinjuku-ku, Tokyo 160-8582, Japan.
}

(Received August 28, 2019)

\begin{abstract}
Advances in genomic medicine have enabled the development of precise cancer therapies (precision cancer medicine) through multigene testing. Toward this end, we have developed a novel clinical sequencing system called PleSSision (Pathologist edited, Mitsubishi Space Software supervised clinical sequence system for personalized medicine) that performs amplicon exome sequencing targeting 160 cancer genes. Using this system, we have examined more than 600 cases over 3 years, and have identified druggable gene alteration in approximately $60 \%$ of the cases. Performing such clinical sequencing requires management of the sample quality and sequencing by pathologists and laboratory technicians; bioinformatics analysis by biomedical scientists; and patient care by nurses and pharmacists, all based on specific skills and knowledge of genomics. In addition, patients diagnosed with a hereditary cancer syndrome based on clinical sequencing results must receive care from a genetic counselor and a medical doctor with expertise in genetics. Recently, poly (ADP-ribose) polymerase (PARP) inhibitors and immune checkpoint inhibitors have been used in the treatment of patients with hereditary cancer syndromes, so collaboration involving other medical staff, especially genomic pharmacists, is also required. In this session, we provide an overview of cancer genomic medicine and emphasize the role that genomic pharmacists play in cancer precision medicine.
\end{abstract}

Key words_ - precision medicine; multigene testing; genomic pharmacist

\section{1. はじめに}

ゲノム医療とは，これまで平均的な患者向けにデ ザインされていた治療を, 遺伝子, 環境, ライフス タイルに関する個々人の違いを考慮して, 最適な疾 病の予防や治療法を確立することを意味する。こう したゲノム医療を実現可能にしたのは，言うまでも なく, 次世代シーケンサーに代表される高精度・高 出力の核酸解析機器の登場と, 大量のゲノムデータ を高速で解析するバイオインフォマティクス技術の 進歩に基づく技術革新である。これまでの医療にお いても，遺伝子を調べて疾患の診断や治療方針の策 定を行うことは, 10 年以上前から実施されてき た.しかし，これまでのように標的となる 1 つの遺 伝子の特定の箇所を調べる方法から，一度に数十〜

慶應義塾大学医学部腫瘍センターゲノム医療ユニット (干160-8582 東京都新宿区信濃町 35)

*e-mail: hnishihara1971@ keio.jp

本総説は, 日本薬学会第 139 年会シンポジウム S49 で

発表した内容を中心に記述したものである.
数百，あるいは全遺伝子を一度に調べる手法にシフ トしていく中においては，その圧倒的な解析スピー ドから生まれる解析の安定性, 精度が問題となり, こうしたシステムを医療の現場で患者の治療に直接 的に利用するためには，なんらかの承認を与える必 要がある.また，そうしたシステムを医療インフラ として国内に普及・整備するためには，行政による 正しい方向付けとネットワーク化, 法的整備, さら に人材育成のビジョンが必要である。本稿において は，2019年に保険診療で遺伝子パネル検査の運用 が始まったわが国におけるがんゲノム医療の現状 と, 必要な人材育成について述べる.

\section{2. がん遺伝子パネル検査}

がんゲノムパネル検査は，諸外国においては研究 レベルではなく既に一般診療の中に取り入れられて いる。米国では Foundation Medicine 社の Foundation One という 314 遺伝子を解析するパネル検査 が 5 年前から受託型臨床検査として導入され，これ までに 10 万人以上の解析実績を有する。また 


\section{"PleSSision" test is employed in more than 25 hospitals}

\section{Cancer Tissue}

(FFPE)

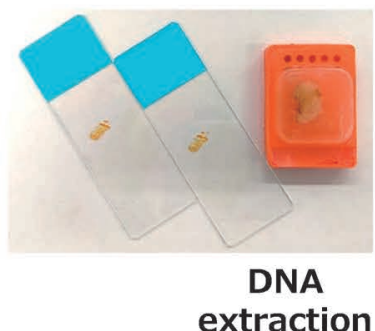

extraction

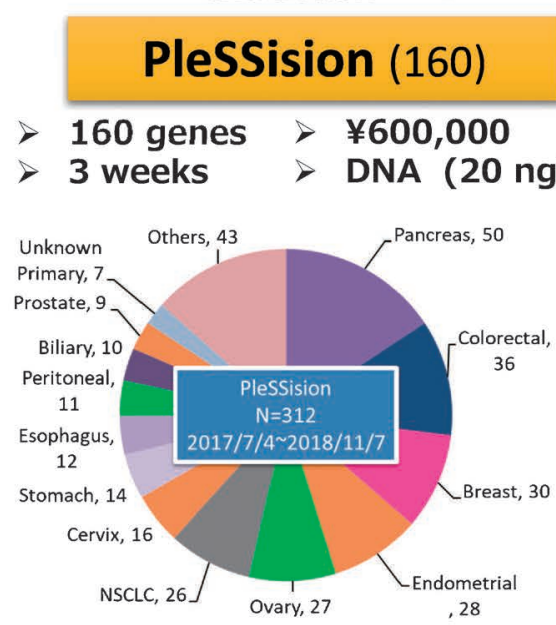

Driver gene alteration : $\mathbf{9 2 \%}$

Druggable gene alteration : $59 \%$

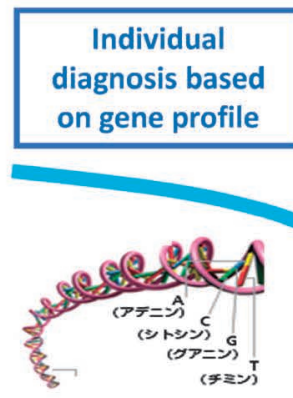

(¥ミン

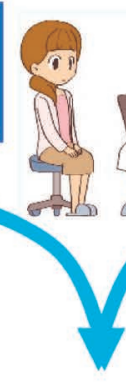

PBMC as a normal control

Individual treatment based on gene profile

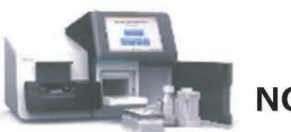

NGS analysis

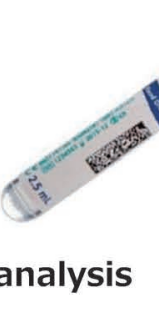

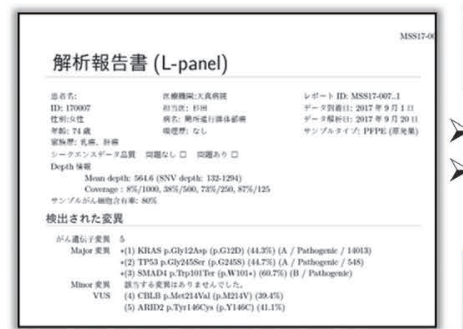

Gene profile report by Mitsubishi Space Software

\section{Plessision-Exome}

19296 genes $>\quad ¥ 1,000,000$

4-6 weeks > DNA (200 ng)

Whole exome sequence

Since 2019.3.11

Fig. 1. Outline of Outsourced "PleSSision" Test

Memorial Sloan Kettering Cancer Center は MSKIMPACT という 468 遺伝子を解析する検査システ ムを開発し，院内検査として検査を実施し一万人以 上の解析結果を報告している。 ${ }^{1)}$ わが国において は, 平成 26 年 7 月に閣議決定された健康・医療戦 略において「環境や遺伝的背景といつたエビデンス に基づく医療を実現するため，その基盤整備や情報 技術の発展に向けた検討を進める」，「ゲノム医療の 実現に向けた取り組みを推進する」などの取決が掲 げられ，平成 27 年には「ゲノム医療実現推進協議 会」が設置された。がん領域に関しては平成 29 年 度に「がんゲノム医療中核拠点病院等」の承認が始 まった。承認された機関はがんゲノムに関する情報 を「がんゲノム情報管理センター（Center for Cancer Genomics and Advanced Therapeutics; C-CAT)」 に集約させ日本のがんゲノムデーターベース構築を 目指している. 国は，がんゲノム医療の均てん化を 目指すという方向性を明瞭化しているが，現在大部

分のがん遺伝子パネル検査が自費診療であること や，先進医療の枠に含まれていても検査適応が限定 されていること, 民間医療機関におけるデー夕の帰 属問題等，目標とする体制構築は容易でない.

日本において，2015 年に京都大学の武藤らが臨 床検査として日本初のがんゲノムパネル検査 「OncoPrime 検査」を開始した。これは米国のクイ ンタイルズ社を通して 220 遺伝子の検査を行うシス テムでこれまでに 300 名程度の解析実績を有す る. ${ }^{2)} 2018$ 年には国立がん研究センター（National

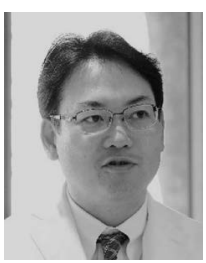

西原広史
1995 年, 北海道大学医学部医学科卒 業. クリニカルシークエンスシステム 「PleSSision 検査」を開発. 2017 年 11 月, 慶應義塾大学医学部腫瘍センター ゲノム医療ユニット長・特任教授とな り, 同病院のがんゲノム医療中核拠点 病院認定に尽力した。 2019 年 4 月よ り, 同大学医学部臨床研究推進セン 夕一教授。 


\section{Cancer Genomic Medicine in JAPAN}
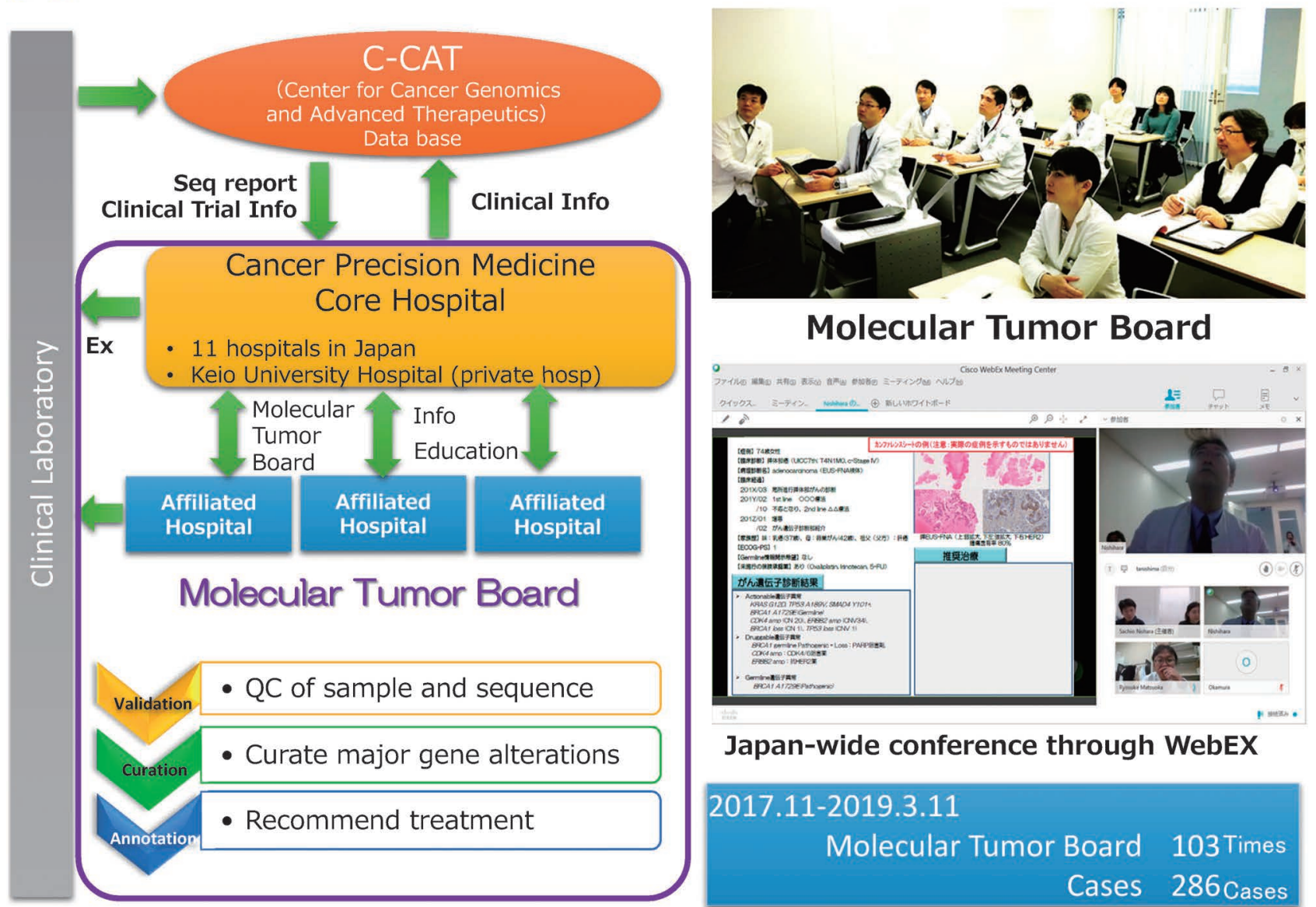

Japan-wide conference through WebEX

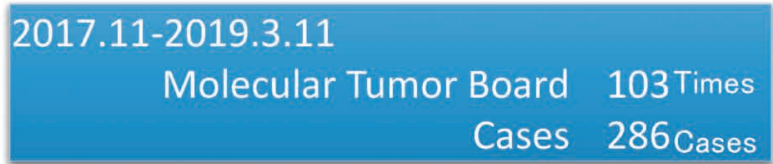

Fig. 2. Operation of Cancer Gene Profiling Test under Insurance Practice

Cancer Center；NCC）が中心となって開発した NCC オンコパネルが先進医療 B として開始され 350 症例の解析が行われた. 2016 年，筆者らが中心 となり北海道大学病院にて院内完結型検査として 160 遺伝子を調べる CLHURC 検査を開発した。そ の後, この CLHURC 検査は外注型検査 PleSSision 検査に進化し，現在では国内 25 医療機関で導入・ 実施され，解析症例は 600 を超えている (Fig. 1).

\section{3. 保険診療下での遺伝子パネル検査の開始}

がんゲノム医療に係る高い専門性を有する機関の 整備として厚生労働省は，平成 29 年度に「がんゲ ノム医療中核拠点病院等」の承認を決めた。これ は，がんゲノム医療の均てん化を目指し，一定水準 を持つ医療機関が中心となつて，遺伝子パネル検査 (多数の遺伝子を一度に解析する網羅的がん遺伝子 検査）を実施し，その結果に基づく個別化医療を推 進することを狙ったもので，全国に 11 力所の中核
拠点病院と，その下に連携病院を配置して日本全体 を網羅する，というがんゲノム医療ネットワーク化 の構図である。また，これらの機関は，がんゲノム に関する情報を「がんゲノム情報管理センター」に 集約させる義務を負い，日本全体におけるがんゲノ ムデータベースを構築することを目指している (Fig. 2). 2018 年 2 月, 全国に 11 のがんゲノム医 療中核拠点病院が認定され, 同年 3 月には 100 の連 携医療機関が認定され，日本国内のがんゲノム医療 体制が整備された。がんゲノム医療中核拠点病院に 求められる機能は多岐にわたり，1）精度管理され た病理検体の取り扱いと遺伝子パネル検査の実施,

2）エキスパートパネルと呼ばれる専門家会議の開 催による正確な遺伝子検査結果の解釈と患者対応,

3）生殖細胞系列変異の検出時の遺伝カウンセリン グ対応，4）セキュリティーの担保されたゲノム情 報, 患者情報の取り扱い，5）臟器横断的なゲノム 


\section{Cancer Gene Profiling test as a clinical testing}

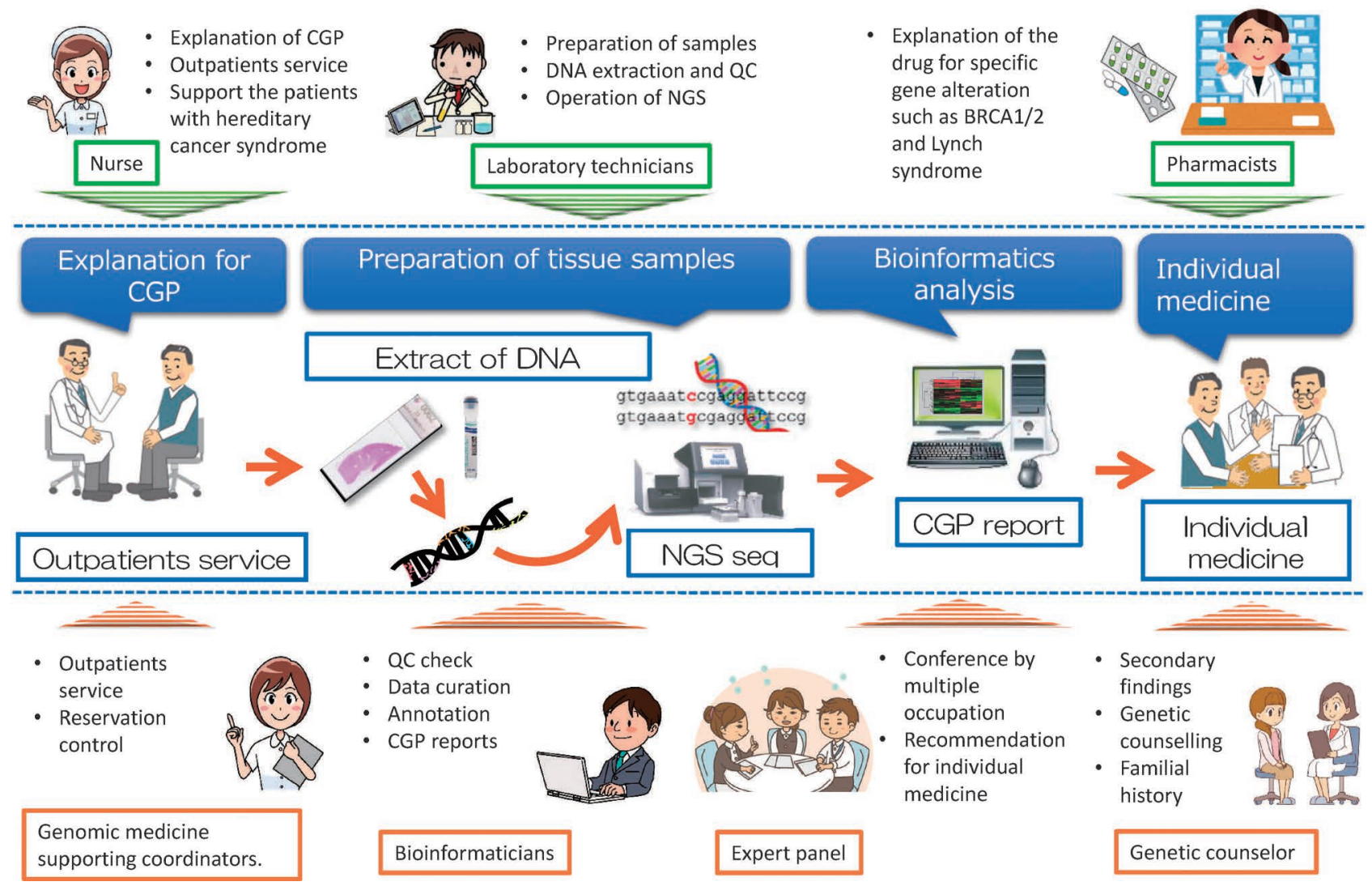

Fig. 3. Human Resources Required for Promoting Cancer Genomic Medicine

解析用検体の採取とバンキング，6）先進医療 B や 患者申出療養制度を活用した先進的な治療への対応, 7)がんゲノム医療に関与する人材育成や研究活動, など，アカデミア及び診療機関としての総合力が求 められる．また，各中核拠点病院は，それぞれの連 携病院と診療ネットワークを形成し, 遺伝子パネル 検査の実施, 解釈, 検查後の治療対応について連携 することが求められている。 しかし，現状において は，どのような遺伝子パネル検査を実施するのか， あるいは，治療についても保険適用外となる場合の 対応など, 現場の課題は山積しており，まさに医療 機関同士のチーム編成がカギを握つている.

\section{4. がんゲノム医療に必要な人材の育成}

がんゲノム医療の実践において遺伝子解析が必要 となるが,こうした遺伝子検査システムは, 病理 医・臨床検査技師による検体の品質管理とシーケン スの実践，さらにバイオインフォマティクス専門家 によるデー夕処理における精度管理, 個人情報保護
が必須のプロセスである．また，患者に直接接する 看護師や投薬説明を行う薬剤師においても，一般的 なゲノム医療の知識を身に付ける必要がある。特 に，二次的所見として見つかる生殖細胞系列バリア ントを有する症例に対して遺伝カウンセリングを行 うには, 遺伝カウンセラーや臨床遺伝専門医との連 携が必須である. したがって，がんゲノム医療の推 進には，多職種によるチーム医療体制構築が必須で あり, poly (ADP-ribose) polymerase (PARP) 阻害 剂や免疫チェックポイント阻害剂のように遺伝性腫 瘍症候群に対して投薬が行われる薬剤が注目される 昨今においては，薬剤師が果たす役割は大きい (Fig. 3)。筆者はこれまでに，がんクリニカルシー ケンスの臨床実装を担当する中で, 厚労科研「ゲノ 么医療実施体制の構築と人材育成に関する研究」 (代表; 中釜 斉), Japan Agency for Medical Research and Development (AMED) 臨床ゲノム情 報統合データベース整備事業（代表 ; 武藤 学）等 
の研究分担者として，がんゲノム医療に係わる医療 従事者の人材育成に関与してきた。 その体験の中 で，ゲノム医療において検査を担当する臨床検査技 師，患者対応に当たる看護師，ゲノムデー夕に基づ いて投薬される分子標的治療薬の調剤に当たる薬剤 師，また遺伝子診断報告書の作成において欠かせな いバイオインフォマティクス専門家が国内において 圧倒的に不足している現状に直面してきた。 そうし た状況を踏まえ，現在，AMED ゲノム創薬基盤推 進研究事業（代表；豊岡伸一）のプロジェクトにお いて, 複数のゲノム医療人材を育成するプロジェク 卜を担当しているが，その対象者は，医師はもちろ んのこと, 看護師, 臨床検査技師, 薬剤師, バイオ インフォマティクス専門家となっており，様々な学 会と連携しつつ，可及的速やかにこうした人材の育 成を行うプログラムが実施されている。 また，学会 認定の資格制度の設定と同時に，ゲノム医療人材の キャリアパスの整備も重要であり，例えば医療者の 資格を持たない認定遺伝カウンセラーやバイオイン フォマティクス専門家が医療機関で働く際の職位の 設定にも配慮が必要である.

利益相反＼cjkstart開示すべき利益相反はない.

\section{REFERENCES}

1) Zehir A., Benayed R., Shah R. H., Syed A., Middha S., Kim H. R., Srinivasan P., Gao J., Chakravarty D., Devlin S. M., Hellmann M. D., Barron D. A., Schram A. M., Hameed M., Dogan S., Ross D. S., Hechtman J. F.,
DeLair D. F., Yao J., Mandelker D. L., Cheng D. T., Chandramohan R., Mohanty A. S., Ptashkin R. N., Jayakumaran G., Prasad M., Syed M. H., Rema A. B., Liu Z. Y., Nafa K., Borsu L., Sadowska J., Casanova J., Bacares R., Kiecka I. J., Razumova A., Son J. B., Stewart L., Baldi T., Mullaney K. A., AlAhmadie H., Vakiani E., Abeshouse A. A., Penson A. V., Jonsson P., Camacho N., Chang M. T., Won H. H., Gross B. E., Kundra R., Heins Z. J., Chen H. W., Phillips S., Zhang H., Wang J., Ochoa A., Wills J., Eubank M., Thomas S. B., Gardos S. M., Reales D. N., Galle J., Durany R., Cambria R., Abida W., Cercek A., Feldman D. R., Gounder M. M., Hakimi A. A., Harding J. J., Iyer G., Janjigian Y. Y., Jordan E. J., Kelly C. M., Lowery M. A., Morris L. G. T., Omuro A. M., Raj N., Razavi P., Shoushtari A. N., Shukla N., Soumerai T. E., Varghese A. M., Yaeger R., Coleman J., Bochner B., Riely G. J., Saltz L. B., Scher H. I., Sabbatini P. J., Robson M. E., Klimstra D. S., Taylor B. S., Baselga J., Schultz N., Hyman D. M., Arcila M. E., Solit D. B., Ladanyi M., Berger M. F., Nat. Med., 23, 703-713 (2017).

2) Kou T., Kanai M., Yamamoto Y., Kamada M., Nakatsui M., Sakuma T., Mochizuki H., Hiroshima A., Sugiyama A., Nakamura E., Miyake H., Minamiguchi S., Takaori K., Matsumoto S., Haga H., Seno H., Kosugi S., Okuno Y., Muto M., Cancer Sci., 108, 14401446 (2017). 